\title{
Retroactive or Prospective? Determining the Scope of Hong Kong's New Insolvency Law
}

\author{
Charles D Booth* and Philip St 7 Smart** \\ * Acting Dean and Associate Professor, Faculty of Law, University of Hong \\ Kong. BA, Yale University, 1981; JD, Harvard Law School, 1984 \\ **Associate Professor, Faculty of Law, University of Hong Kong. LLB, \\ University of London, 1982; LLM, University of London, 1983
}

\section{Introduction}

As regular readers of the International Insolvency Review will be aware, over the last two years significant amendments have been made to Hong Kong's insolvency law in the form of amendments to the Bankruptcy Ordinance ${ }^{1}$ and the Companies Ordinance. ${ }^{2}$ Major changes were made to the Bankruptcy Ordinance through the Bankruptcy (Amendment) Ordinance $1996^{3}$ (the $\mathrm{BAO}$ ), which finally came into operation on 1 April 1998. The BAO not only amended the Bankruptcy Ordinance; in addition, pursuant to s. 76 of the $\mathrm{BAO}$, new s. 266B (unfair preference) was added to the Companies Ordinance. Earlier, on 10 February 1997, new s. 264A (interest on debts) of the Companies Ordinance came into force. ${ }^{5}$ Unfortunately, in a few important areas the amending legislation incorporating these changes did not clarify whether the amendments were intended to have any retrospective effect. This omission has already led to one case, Re Setaffa Investments Ltd (In Liquidation) [1998] 2 HKLRD 236, which addressed this issue in the context of s. 264A of the Companies Ordinance. The first part of this article discusses the recent decision by the Court of First Instance in Setaffa Investments. The second part addresses

1. Laws of Hong Kong 1999 (LHK), Chapter 6.

2. Ibid., Chapter 32.

3. Ordinance No.76 of 1996 (24 December 1996). For a discussion of the important changes made by this ordinance, see Charles D Booth, "Leaping forward to 1997: Bankruptcy Law Reform in Hong Kong" [1997] 6 IIR 183.

4. Pursuant to the Bankruptcy (Amendment) Ordinance 1996 (76 of 1996) (Commencement) Notice 1998 (LN 158 of 1998)
(20 February 1998). The Bankruptcy (Amendment) Rules 1998 (LN 77 of 1998), the Bankruptcy (Forms) (Amendment) Rules 1998 (LN 81 of 1998), the Bankruptcy (Fees and Percentages) (Amendment) Order 1998 (LN 83 of 1998), and the Proof of Debts (Amendment) Rules 1998 (LN 85 of 1998) also came into operation on 1 April 1998.

5. Companies (Amendment) Ordinance 1997 (Ordinance No.3 of 1997) (16 January $1997)$, s. 43 .

Copyright (C) 1999 John Wiley \& Sons, Ltd. 
more general retroactivity issues that arise with regard to the amendments made by the BAO to both the Bankruptcy and Companies Ordinances.

\section{Setaffa Investments and s. 264A of the Companies Ordinance}

Section 264A deals with interest payable on debts. In particular, subs. (2) is concerned with the payment of interest on debts after a winding-up order has been made or a resolution or a board decision has been taken (i.e. from the date of the winding-up order, board decision, or resolution, as the case may be, to the date of the actual payment of the debts). Section $264 \mathrm{~A}$, which, it will be noted, does not apply to insolvent companies, provides as follows:

"(1) In the winding up of a company, not being an insolvent company, interest is payable in accordance with this section on any debt proved in the winding up, including so much of any debt as represents interest on the remainder.

(2) Any surplus remaining after the payment of debts proved in a winding up referred to in subsection (1) shall, before being applied for any other purpose, be applied in paying interest on those debts in respect of the period during which the debt has been outstanding, in the case of -

(a) a winding up by the court -

(i) where the company has by special resolution resolved that the company be wound up, since the date of the resolution and;

(ii) in any other case, since the date of the winding-up order; and

(b) a voluntary winding up, since the commencement of the winding up

(which must be construed having regard to section $228 \mathrm{~A}(3)(\mathrm{a})$ or 230 , as may be appropriate).

(3) All interest under this section ranks equally, whether or not the debts on which it is payable rank equally.

(4) The rate of interest payable under this section in respect of any debt is whichever is the greater of the following -

(a) the rate specified under section $49(1)$ (b) of the High Court Ordinance (Cap. 4); and

(b) the rate applicable to the debt apart from the winding up."

On 11 April 1983, Setaffa Investments Ltd passed an appropriate resolution to go into voluntary liquidation. After the creditors' proofs were satisfied in full (by November 1991) and after taking into account the costs of the liquidation, approximately $\operatorname{HK} \$ 9.5$ million remained. The liquidators were unsure whether s.264A was to have retrospective or prospective effect. If s. 264A applied retrospectively, then all creditors would be entitled to interest on their debts for the period from April 1983 to the date of the actual payment of the debts in question. ${ }^{6}$

6. The rate of interest would be either that laid down in s. 49 (1) (b) of the High Court Ordinance or the contractual rate initially agreed between the parties. See s.264A of the Companies Ordinance in the text above. 
The court in Setaffa Investments pointed out that in providing that, in the event of a surplus, interest should be payable at the higher of the judgment rate or the contractual rate, s. 264A was following the approach found in s. 189 of the UK Insolvency Act $1986 .{ }^{7}$ As noted by the court, prior to the introduction of s. $264 \mathrm{~A}:{ }^{8}$

"... creditors of a company which was insolvent at the commencement of a winding-up but which later realized a surplus had no right to prove for or to recover interest on their claims in the absence of any express contractual agreement between the company and the creditor. Where there was a contractual entitlement to interest, the creditor was entitled to post-liquidation interest in the event of a surplus."

The transitional provisions in the Insolvency Act 1986 provide, in para. $4(1)$ of Sched. 11, that "[i]n relation to any winding up which has commenced, or is treated as having commenced, before the appointed day, the new law does not apply, and the former law continues to have effect, subject to the following paragraphs". Thus, it is clear that the UK section applies only to liquidations commencing after the section came into effect. However, unlike the Insolvency Act 1986, the Companies (Amendment) Ordinance 1997 failed to include transitional provisions in relation to s. $264 \mathrm{~A} .^{9}$

In framing the issue, the court noted the view of counsel for the liquidators that there were three possible interpretations of the effect of s. $264 \mathrm{~A}$ - that it applies: ${ }^{10}$

(a) retrospectively;

(b) partially retrospectively, in the sense that it affects only assets that remain in the hands of the liquidators and therefore which have not been distributed; or

(c) prospectively.

Counsel for the contributories argued that the new section should be applied only prospectively. In short, his argument was as follows: since s. 264A was not part of codifying legislation, it was deemed to be remedial ${ }^{11}$ and thus altered the previous position regarding the payment of post-liquidation interest that existed on the effective date, which was that there was a "notional crystallization of all claims against the estate as at the date of liquidation and save for the special rule or exception mentioned earlier, nothing is allowed for

7. [1998] 2 HKLRD 236 at 240. (Citing Legislative Council Brief, 17 April 1996, para. 24).

8. [1998] 2 HKLRD 236 at 240.

9. Ibid. The inclusion in the Companies Ordinance after s.264A of the square brackets including a reference to the $\mathrm{UK}$ provision does not have any legislative effect. Ibid. (citing LHK, Interpretation and General Clauses Ordinance, Chapter 1, s. 18).

10. [1998] 2 HKLRD 236 at 241

11. By virtue of s. 19 of the Interpretation and General Clauses Ordinance. 
interest". ${ }^{12}$ Thus, in the absence of clear transitional guidelines, a contributory had a "vested right or expectation" to receive the surplus free from any claims for post-liquidation interest. ${ }^{13}$ Counsel for the contributories relied on the fundamental rules of statutory interpretation, stated in 23 Halsbury's Laws of Hong Kong, para. 365.087: ${ }^{14}$

\footnotetext{
"The general rule is that all statutes are prima facie prospective, and retrospective effect is not to be given to them unless, by express words or necessary implication, it appears that this was the intention of the legislature. Similarly, the courts will construe a provision as conferring power to act retrospectively only when clear words are used. At the same time, if the words of the statute are clear and unambiguous, the courts should not do violence to the natural meaning of the words in order to avoid a retrospective effect. The presumption is bound up with that of preventing a statute from operating to cause unfairness.

By virtue of the presumption, provisions in which a contrary intention does not appear have been held neither to impose new liabilities in respect of events taking place before their commencement, nor to relieve persons from liabilities then existing."
}

In contrast, the Official Receiver (who appeared as amicus) argued that the absence of transitional provisions led to ambiguity and that to resolve this ambiguity one had to turn to the underlying policy of s. $264 \mathrm{~A}$ - namely, to remedy the injustice suffered by creditors who were not entitled to interest under their contracts with the company. ${ }^{15}$ The Official Receiver urged adoption of a "hybrid solution" which would allow s. 264A to be applied to all distributions made after 10 February 1997, the day the section came into operation. In other words, the Official Receiver did not argue that s. $264 \mathrm{~A}$ was to have full retrospective application, but rather that it was retrospective only in relation to liquidations commenced prior to the coming into operation date of the section (10 February 1997) in which there were funds that had not been distributed prior to that date. ${ }^{16}$

The court, however, rejected the submissions of the Official Receiver in favour of the argument based on the need for clear language if a section is to be given retrospective effect. In the absence of such language, the court held that s. 264A did not have retrospective effect, ${ }^{17}$ noting that " $[\mathrm{t}]$ his is consistent with the general approach of the court that existing rights and obligations should not be impaired or taken away in the absence of clear and unambiguous language". ${ }^{18}$ The court pointed out that if the section were interpreted as having partial retroactive effect, there exist two potential classes of persons whose rights could be adversely affected - creditors with a contractual interest

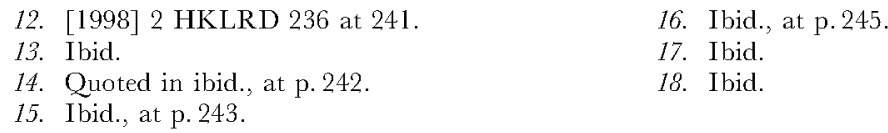


entitlement and contributories. ${ }^{19}$ Thus, the court held that s. $264 \mathrm{~A}$ has prospective effect and applies only to liquidations commenced after the section came into effect, that is, after 10 February 1997.

This surely is the proper result. It appears that neither of the law reform bodies that studied this issue (i.e. the Law Reform Commission of Hong Kong and its Sub-Committee on Insolvency) addressed the question of retrospectivity. Moreover, the fact that the legislative draftsmen in Hong Kong had not copied the transitional provisions found in the English legislation may be "attributable to sheer oversight". ${ }^{20}$ The interesting arguments put forth by the Official Receiver were most likely an effort to remedy this oversight after the fact. However, the court was correct in rejecting such an argument in favour of an approach that requires clear language to make a section retrospective.

\section{The applicable dates for the Bankruptcy (Amendment) Ordinance 1996}

Section 1(2) of the BAO provides that the Ordinance would "come into operation on a day to be appointed by the Secretary for Financial Services by notice in the Gazette" and this date was later set as 1 April 1998. ${ }^{21}$ Section 99 of the $\mathrm{BAO}$ sets out the transitional provisions as follows:

"(1) Subject to the subsection (2), where before this Ordinance comes into operation -

(a) a petition in bankruptcy has been presented;

(b) a receiving order or adjudication in bankruptcy has been made, under the principal Ordinance, then the principle Ordinance as it existed before being amended by this Ordinance continues to apply to proceedings in respect of such a petition, receiving order or adjudication in bankruptcy.

(2) Sections 30 to $30 \mathrm{C}$ of the principal Ordinance as enacted by section 20 of this

Ordinance apply to proceedings referred to in subsection (1)."

Accordingly, pursuant to subs. (1), the old bankruptcy law will continue to apply in bankruptcy cases commenced prior to 1 April $1998 .{ }^{22}$ The sole exception is contained in subs. (2), which refers to the new discharge provisions contained in new ss 30 to $30 \mathrm{C}$ of the Bankruptcy Ordinance. ${ }^{23}$

19. Ibid

20. Ibid., at p. 246. As Le Pichon J noted: "In this regard, that will hardly be the first time that it will have occurred when Hong Kong legislation is based on UK legislation".

21. See op. cit., n. 4.

22. This result is also reflected in the transitional provisions enacted in $5.98\{1\}$ of the Bank- ruptcy (Amendment) Rules 1998, s. 3 of the Bankruptcy (Fees and Percentages) (Amendment) Order 1998, and s. 8 of the Proof of Debts (Amendment) Rules 1998.

23. This result is also reflected in the transitional provisions enacted in s. $98\{2\}$ of the Bankruptcy (Amendment) Rules 1998. 


\section{A. The new discharge provisions}

The amendments to the discharge provisions are among the most important contained in the BAO. Under the old bankruptcy law, few bankrupts were able to receive a discharge ${ }^{24}$ and, thus, for the majority of debtors bankruptcy became a "life sentence". ${ }^{25}$ The new discharge provisions are intended to give most bankrupts a "fresh start" after a reasonable period of time - which will normally be four or five years, depending, inter alia, on whether the debtor had previously been adjudicated bankrupt. ${ }^{26}$

The new s.30G (introduced by s. 20 of the BAO) addresses the position in relation to individuals who were adjudicated bankrupt before 1 April 1998 (the day that the new discharge provisions came into operation) but had not received a discharge by that date:

"(1) Subject to subsection (2), sections 30 to $30 \mathrm{~B}$ apply to a bankruptcy order made before those sections come into operation in respect of which no order to discharge the bankrupt has been made.

(2) Where a bankrupt -

(a) has not previously been adjudged bankrupt and the bankruptcy order was not made less than 42 months; ${ }^{27}$ or

(b) has previously been adjudged bankrupt and the current bankruptcy order was not made less than 54 months, ${ }^{28}$

before sections 30 to $30 \mathrm{~B}$ came into operation, he shall be deemed to be discharged from bankruptcy 12 months after the day this section comes into operation unless, during that 12 month period, the trustee or a creditor files an objection on a ground set forth in section $30 \mathrm{~A}(4)$ (a) to (h), in which case section $30 \mathrm{~A}$ applies and the court shall deal with the matter as it sees fit."

Thus, in regard to the retroactivity of the new discharge provisions, the BAO is quite clear in both ss $99(2)$ and 20. Section 99(2) explicitly provides for an exception to the application of the old bankruptcy law in bankruptcy cases commenced prior to 1 April 1998, and s. 20 (through the addition of new s. $30(\mathrm{C})$ explicitly applies the new discharge provisions to bankrupts who are adjudicated bankrupt prior to 1 April 1998. Thus, rather than continuing to languish in bankruptcy indefinitely, the majority of individuals adjudicated bankrupt prior to 1 April 1998 will be discharged from bankruptcy on 1 April 1999.

The language regarding retroactivity included in both ss $99(2)$ and 20 is precisely the type of clear and compelling language that meets the standard set

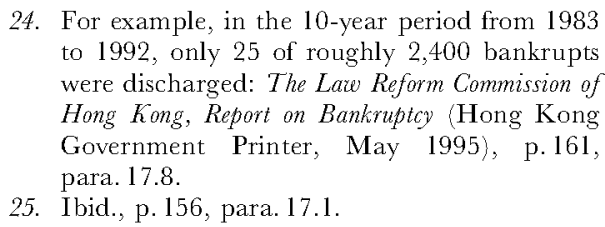

24. For example, in the 10 -year period from 1983 to 1992 , only 25 of roughly 2,400 bankrupts were discharged: The Law Reform Commission of Hong Kong, Report on Bankruptcy (Hong Kong Government Printer, May 1995), p. 161, para. 17.8.

25. Ibid., p. 156 , para. 17.1 .

26. See Bankruptcy Ordinance, new ss $30-30 \mathrm{C}$.

27. As amended by s. 101 (a) of the Law Reform (Miscellaneous Provisions and Minor Amendments) Ordinance 1997 (Ordinance No.80 of 1997).

28. As amended by ibid., s. 101 (b). 
out in Setaffa Investments. This also demonstrates that the draftsmen focused on some of the retroactivity issues. However, as demonstrated in the following section, these issues were not fully considered in regard to other provisions in the BAO.

\section{B. Avoidance powers in bankruptcy cases}

At first glance, the arrangement for the application of the new bankruptcy provisions appears to be as follows: the new bankruptcy law is to be prospective in application and to apply in cases commenced on or after 1 April 1998, and the old bankruptcy law is to continue to apply in cases commenced prior to 1 April 1998 (with the exception of the discharge provisions included in s. 20 of the $\mathrm{BAO}$, as discussed above). However, upon further reflection, the matter is much more complicated. Bankruptcy law is not only prospective in its application; there are many aspects of bankruptcy that are retrospective. For example, a bankruptcy trustee may seek to exercise his avoidance powers to attack transactions entered into by the debtor pre-bankruptcy. Pursuant to new ss 50 and 51 of the Bankruptcy Ordinance, ${ }^{29}$ a trustee in a bankruptcy case commenced after 1 April 1998 may attack unfair preferences to associates ${ }^{30}$ of the debtor which occurred within two years of the filing of the petition, and to non-associates which occurred within six months of the filing of the petition. (Under old s. 49 of the Bankruptcy Ordinance, there was only a six-month avoidance period, which applied to all transferees.) Pursuant to new ss 49 and 51 of the Bankruptcy Ordinance, a trustee may also attack transactions at an undervalue occurring within five years of the filing of the bankruptcy petition. ${ }^{31}$ (Under old s. 47 of the Bankruptcy Ordinance, a trustee could attack certain settlements occurring within two years - and, in some cases, within 10 years - of the filing of the petition.) However, there is no language in the transitional provisions in s. 99 which provides that the new avoidance powers are to have retroactive effect. Therefore, these new powers should apply only to transactions occurring on or after 1 April 1998. In the absence of any transitional provisions dealing with such powers, the question then arises as to what law should apply to transactions occurring before 1 April 1998.

The new avoidance powers are based on ss 339 to 343 of the UK Insolvency Act 1986. When those provisions were enacted, para. 17(1) of Sched. 11 to the Act explicitly addressed this problem as follows:

"(1) A preference given, assignment made or other transaction entered into before the appointed day shall not be set aside under any of sections 339 to 344 of this Act except to the extent that it could have been set aside under the law in force immediately before that day.

\footnotetext{
29. BAO, s. 36 .

30. "Associates" are defined in new s. $51 \mathrm{~B}$ of the

Bankruptcy Ordinance (as amended by BAO, s. 36$\}$.
}

31. See BAO, s. 36 .

Copyright (C) 1999 John Wiley \& Sons, Ltd.

Int. Insolv. Rev., Vol. 8: 27-37 (1999) 
(2) References in sub-paragraph (1) to setting aside a preference, assignment or other transaction include the making of any order which varies or reverses any effect of a preference, assignment or other transaction."

Under the UK approach, the new law was to have retroactive effect to the extent that it overlapped with the previous law. Thus, to the extent that the new law incorporated the old law, the new law could be used to set aside a transaction occurring prior to the date on which the new law came into operation. However, to the extent that the new law extended the scope of the old law, the new law could not be used to set aside a transaction occurring prior to the date on which the new law came into operation.

Unfortunately, there is no equivalent of Sched. 11 , para. 17 in the BAO. At first glance, it might appear that in bankruptcies commenced on or after 1 April 1998 no law would apply in relation to transactions occurring prior to that date, since s. 34 of the BAO repeals old s. 47 (the predecessor section of new s. 49), and s. 36 of the BAO repeals, inter alia, old s. 49 (the predecessor provision of new s. 50). However, these repeals must be interpreted in the light of s. 23 of the Interpretation and General Clauses Ordinance, which states (in part):

"Where an Ordinance repeals in whole or in part any other Ordinance, the repeal shall not-

.

(b) affect the previous operation of any Ordinance so repealed or anything duly done or suffered under any Ordinance so repealed;

(c) affect any right, privilege, obligation or liability acquired, accrued or incurred under any Ordinance so repealed;

(d) affect any penalty, forfeiture or punishment incurred in respect of any offence committed against any Ordinance so repealed; or

(e) affect any investigation, legal proceedings or remedy in respect of any such right, privilege, obligation, liability, penalty, forfeiture or punishment as aforesaid; and any such investigation, legal proceeding or remedy may be instituted, continued or enforced, and any such penalty, forfeiture or punishment may be imposed, as if the repealing Ordinance had not been passed."

Thus, the avoidance powers in old ss 47 and 49 continue to apply in bankruptcy cases commenced on or after 1 April 1998 to avoidable transactions occurring before that date. This does not cause great difficulties in regard to fraudulent preferences because the six-month avoidance period would only have been relevant in bankruptcy cases commenced before 1 October 1998. The situation involving transactions at an undervalue is more troublesome because the period of avoidance under old s. 47 extends back for up to 10 years. Thus, the irony is that it will take a full decade for new s. 49 to replace fully old s. 47; the old law will continue to apply to transactions occurring prior to 
1 April 1998 in bankruptcies commenced up to 1 April 2008. This surely could not have been intended by either the Law Reform Commission of Hong Kong or its Sub-Committee on Insolvency. Such a consequence demonstrates the problems that arise when amending legislation does not give proper attention to transitional issues.

The practical effect of the application of the new avoidance powers may be illustrated by way of six examples:

1. Assume that a bankruptcy commenced on 1 September 1998 and that the date of an alleged unfair preference was 1 June 1998. The new unfair preference law would apply.

2. Assume that a bankruptcy commenced on 1 September 1998, but the date of an alleged unfair preference was 30 March 1998. The new law, not being retroactive, cannot apply to this transaction. Therefore, the trustee should look to the old fraudulent preference law (old s. 49) and determine whether the old law would apply to the facts.

3. Assume that a bankruptcy commences on 1 March 1999 and that the date of an alleged unfair preference was 1 January 1998. Also assume that the alleged preference was in favour of the bankrupt's spouse - an "associate" under new s. $51 \mathrm{~B}(2)$ - in respect of whom the avoidance period extends back 24 months. The alleged preference, although taking place within the 24-month period, cannot be attacked under the new law since the new provisions are not retroactive. The old fraudulent preference law does not apply, because there were no provisions in the old law for attacking transactions outside the six-month period. (It can be seen from this example that a trustee will not be able to gain the full reach of this extended recovery period against associates until 1 April 2000.)

4. Assume that a bankruptcy commences on 1 March 2002 and that an alleged transaction at an undervalue occurs on 1 May 1999. The new provisions for avoiding transactions at an undervalue would apply.

5. Assume that a bankruptcy commences on 1 March 2002 and that an alleged transaction at an undervalue occurred on 1 March 1998. The new law, not being retroactive, cannot apply to this transaction. Therefore, the trustee should look to the old law for avoiding certain settlements (old s.47) and determine whether the old law would apply to the facts.

6. Assume that a bankruptcy commences on 1 March 2002 and that an alleged transaction at an undervalue occurred on 1 March 1996. The new law, not being retroactive, cannot apply to this transaction. Moreover, in any event, the new law would not apply because the transaction falls outside the new five-year avoidance period. However, the transaction does fall within the 10-year period of old s. 47 and the trustee should determine whether the transaction would be subject to avoidance under that provision. 


\section{Unfair preferences and the consequential amendment to the Companies Ordinance}

The new unfair preference avoidance power also applies to corporate liquidations, since s. 76 of the BAO amends the Companies Ordinance by adding new s. 266B, which is entitled "Fraudulent preference deemed to be an unfair preference". This section provides:

"(1) On and after the day section 36 of the Bankruptcy (Amendment) Ordinance 1996 (76 of 1996) (the 'amending Ordinance') comes into operation, where the winding up of a company commences on or after that date -

(a) a reference in section 266 or $266 \mathrm{~A}$ of this Ordinance to fraudulent preference shall be deemed to be a reference to an unfair preference as provided for in section 50; and

(b) a reference in section 266 of this Ordinance to a period of 6 months shall be deemed to be a reference to a period of -

(i) 6 months; or

(ii) 2 years in the case of a person who is an associate as provided for in section 51B, of the Bankruptcy Ordinance (Cap.6) (the 'principal Ordinance').

(2) Where the winding up of a company commences before the amending Ordinance comes into operation, the provisions of the principal Ordinance as it existed before being amended by the amending Ordinance apply in respect of sections 266 and 266A of this Ordinance."

Thus, pursuant to s. $266 \mathrm{~B}(1)$, where the winding-up of a company commences on or after 1 April 1998, the new unfair preference terminology will be applicable. Pursuant to subs. (2), where the winding-up of a company commences before 1 April 1998, the old fraudulent preference provisions will be applicable.

The language in new s. 266B of the Companies Ordinance, unlike in new s. 50 of the Bankruptcy Ordinance, uses the language "where the winding up of a company commences on or after that date". However, it is not implicit in this language that the new unfair preference provision should have retroactive effect. Such a result would have required clear and unambiguous language. Thus, the result is the same as under s. 50 of the Bankruptcy Ordinance. It will take until 1 April 2000 for a liquidator to get the full benefit of the new twoyear recovery period against associates.

\section{Conclusion}

It is clear from an analysis of the transitional provisions in the recent Hong Kong insolvency enactments that not enough attention has been given to the question of retroactivity. The unintended result is that some of the old insolvency provisions will continue to apply for almost another decade. At the most practical level, the first thing to be aware of is that when inserting the new legislative provisions into one's looseleaf Bankruptcy Ordinance binder, old 
pages should not be tossed into the rubbish bin. To diminish the likelihood of litigation relating to the applicable dates of the new enactments, it would be helpful if the new insertions for the Bankruptcy and Companies Ordinances included copies of both the old and the new provisions, with footnotes indicating the relevant dates of application. More generally, it is crucial that the legal draftsmen focus on transitional issues when the new companies winding-up legislation is enacted, as is expected in the next year or two. 